\title{
EMPIRICAL ANALYSIS OF FOOD SECURITY STATUS OF AGRICULTURAL HOUSEHOLDS IN THE PLATINUM PROVINCE OF SOUTH AFRICA*
}

\author{
Enioluwa Jonathan Ijatuyi ${ }^{1 \otimes}$, Abiodun Olusola Omotayo ${ }^{1,2}$, \\ Busisiwe Nkonki-Mandleni ${ }^{2}$ \\ ${ }^{1}$ North-West University, Mafikeng Campus, South Africa \\ ${ }^{2}$ Mangosuthu University of Technology, South Africa
}

\begin{abstract}
This paper gives a succinct report on an investigation into the food security constraints of rural farming households in the North West Province of South Africa. Data presented was gathered across the four districts, and was analyzed using descriptive statistics and inferential statistics. The descriptive results showed that the mean age of rural farmers was 55 years and the average household size was 7 members. Logistic regression results on factors influencing food security in the study showed that variables such as age of the household's head, household feeding rate, the total cost of production, farm income and health expenditure had significant impact on the respondents' food security (at $p<0.05$ ). As shown by Probit regression results, constraints such as the age of household head, food availability, veld fires, market availability, predator invasion, health expenditure and veterinary practices significantly influenced the achievement of food security in the study area. This study concluded that rural farming households were witnessing different dimensions of food insecurity which affected different aspects of their social and economic activities. It is therefore the responsibility of the government to come up with a holistic approach to address the present discrepancy in the national and grass-roots food security status.
\end{abstract}

Keywords: constraints, food security, household, logistic regression, probit regression

\section{INTRODUCTION}

Food is a key necessity of life. Obviously, it accounts for a major part of every household's budget. Therefore, the demand for food is topmost in the hierarchy of human needs as it is essential for a healthy life and vitality. In this regard, Blignaut et al. (2014) opined that approximately 870 million people globally are undernourished with close to 100 million of them living in the Southern African Development Community (SADC) alone. The report also suggested that an estimated 25 percent of South Africans remain food insecure. By way of an introduction, food security exists when all people, at all times, have physical, social and economic access to sufficient, safe and nutritious food to meet their dietary needs and food preference for an active and healthy life (FAO, 2003). Therefore, the achievement of food security is important in any given country (Irohibe and Agwu, 2014).

Food security is a multidimensional concept; that makes accurate measurement and policy targeting quite challenging. In South Africa, for example, various methods to assess food security at household level have been used in the past. These include the Food

*The authors appreciates North West University for the financial support for the success of the research.

\footnotetext{
$\bowtie$ MSc Ijatuyi Enioluwa Jonathan, Department of Agricultural Economics and Extension, North-West University, School of Agricultural Sciences, private bag X 2046, Mmabatho, South Africa, e-mail: ijatuyienioluwa@gmail.com
} 
Ijatuyi, E. J., Omotayo, A. O., Nkonki-Mandleni, B. (2018). Empirical analysis of food security status of agricultural households in the platinum province of South Africa. J. Agribus. Rural Dev., 1(47), 29-38. http://dx.doi.org/10.17306/J.JARD.2018.00397

Insecurity and Vulnerability Information and Mapping System (FIVIMS), Community Survey (CS), the Income and Expenditure Survey (IES), National Food Consumption Survey (NFCS), General Household Survey (GHS), South African Social Attitudes Survey (SASAS) and Labor Force Survey (LFS), to name the most important (Labadarios et al., 2009 as cited by De Cock et al., 2013). Food security at household level remains a subset of the national level, and requires that all individuals and households have access to sufficient food either by producing it themselves or by generating sufficient income to place an effective demand on it.

Presently, South Africa is food secure at the national level, whereas the available data suggests that this is not the case for the households' level; the South African poverty context is particular, given the high inequality in income and asset ownership. Hence, the effect of policy measures towards reducing poverty and household's food insecurity is still unclear in areas that were disadvantaged during the apartheid era, thereby making policy targeting a deeply difficult task (De Cock et al., 2013). The same is true for establishing a holistic link between income, poverty and food security. It is thus interesting to ask and find answers to questions such as what are the socio-economic characteristics of rural farming households in the study area? What are the constraints to food security? And what are the factors that influence the households' food security? Therefore, the purpose of this study is to find solutions to all these problems. Considering these reasons and the above background, this study was undertaken to examine the factors that influenced and constrained food security among rural farming households in the North West province. Specifically, the study aimed to:

- Identify the socio-economic characteristics of the respondents in the study area.

- Determine the factors that influence food security level among farming households in the North West province.

- Analyze the constraints that affect the achievement of food security among farming households in North West province.

\section{EMPIRICAL REVIEW}

\section{Food (in)security in South Africa}

South Africa has been recognized as a food secured country in that it produces sufficient amount of staple food and has the ability to import food where and when required in meeting the national need of the people (NDA, 2013). However, evidence from nationwide studies suggests the existence of a number of food and nutritionally insecure households in the country. Oluwatayo and Rachoene (2017) stated that high unemployment rate, inadequate social welfare systems, and a high HIV/ AIDS infection rate are the contributory factors to food insecurity in South Africa. Furthermore, Oluwatayo and Rachoene (2017) emphasized that food insecurity occurs in the case of insufficient means, and is therefore closely related to widespread poverty. Households lack resources such as land, manpower, access to water, knowledge, technology to produce enough food on their own, and/or the purchasing power to buy the food they need in the market. This stresses the fact that national food security status does not translate to individual and household food security status. Food insecurity and its extent are relatively unknown due to the lack of highquality, unified, up-to date national data and the absence of a food insecurity definition accepted among South African authors (Altman et al., 2009; NDA, 2013).

Alem et al. (2014) used a combination of the Income and Expenditure Survey (IES) for 2005/06 and Wooldridge's (WCML) estimator to capture the food security status in South Africa by finding the difference between per capita calorie availability and per capita calorie needed by a household. They concluded that about 64 percent of South African households are food insecure. This differs from the 50 percent estimate reported by the National Department of Agriculture (NDA, 2013). The study also revealed that food insecurity is highest in Limpopo, Eastern Cape, Mpumalanga, and the North West, all having a proportion of 78 percent, 76 percent, 76 percent and 76 percent (respectively) of food insecure households during that period. However, the Gauteng Province had a low number of households (43 percent) considered to be food insecure. This could result from the high level of urbanization in the province.

One of the recent studies by Shisana et al. (2013) who captured the food security situation in South Africa using a national representative sample found out that about 45.6 percent of the population were food secure (score of 0), 28.3 percent were at risk of hunger (score 1-4) and 26.0 percent experienced hunger (were food insecure). Also, while the lowest rate of hunger was reported in urban formal areas (19.0 percent) the largest percentage of participants who experienced hunger 
Ijatuyi, E. J., Omotayo, A. O., Nkonki-Mandleni, B. (2018). Empirical analysis of food security status of agricultural households in the platinum province of South Africa. J. Agribus. Rural Dev., 1(47), 29-38. http://dx.doi.org/10.17306/J.JARD.2018.00397

(food insecurity) lived in urban informal (32.4 percent) and in rural formal (37.0 percent) localities. The highest at-risk-of-hunger rate was reported in the urban informal (36.1 percent) and rural informal (32.8 percent) areas.

In a provincial-wise analysis, the rate of hunger was the lowest in the Western Cape (16.4 percent) and Gauteng (19.2 percent). This was significantly lower than the rate of hunger in the Eastern Cape (36 percent) and Limpopo (32 percent), the only two provinces with a hunger rate above 30 percent. The result supports the widely held view that food insecurity is a challenge in South Africa. The findings depict the realities of the triple burden of malnutrition (under-nutrition, micronutrient deficiencies and overweight).

\section{METHODOLOGY}

\section{Study area}

The research was conducted in the North West Province, the fourth smallest province in South Africa. The province is completely landlocked and comprises four districts: Ngaka Modiri Molema, Bojanala Platinum, Dr. Kenneth Kaunda and Dr. Ruth Segomotsi Mompati, with Mafikeng as the capital. As regards its location within the country, the province is bordering with
Northern Cape, Free-State, Gauteng and Limpopo provinces. Internationally, the province borders the Republic of Botswana in the west, and it is within the South African Development Community (SADC) countries. The province has a total area of 106,512 square kilometers, taking up 8.7 percent of South Africa's land area, and accounts for a population of 3.2 million in 2010 with 7.1 percent of it mostly in nature (Ijatuyi, 2016). The province is an important food basket in South Africa. Maize and sunflowers are the most important crops; the North West is the major producer of white maize in the country. A map of the four districts with their capital is shown in Fig. 1.

\section{Research method and design}

The study relied on a quantitative method since it involved large samples and a fairly structured data collection procedure. The study further made use of frequency, percentages and regression analyses. A descriptive research design was employed during the course of the research. Shuttleworth (2008), as cited by Ijatuyi (2016), defined a descriptive research design as a scientific method which involves observing and describing the behavior of a subject without influencing it in any way.

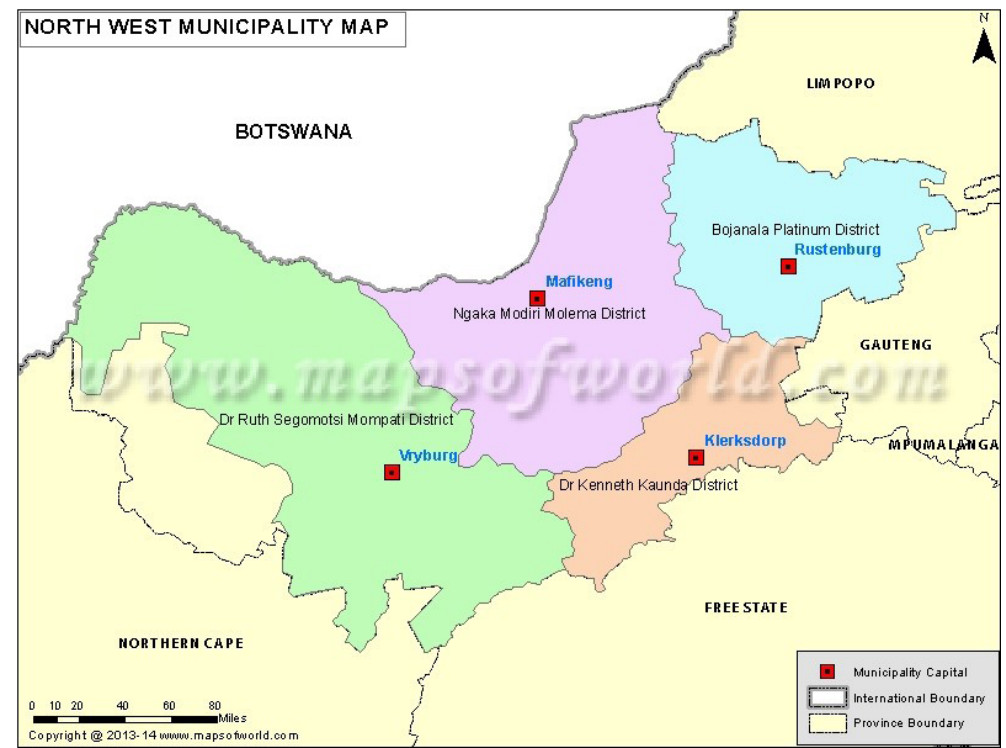

Fig. 1. Map of North West (in purple) showing all the districts with their capital

Source: mapsoftheworld.com (2016). 


\section{Population, sampling procedure and sample size of the study}

According to a media release of DAFF (2016), the study population were rural farmers in the province, from which a sample size of 144 was selected using Krejcie and Morgan (1970) sample size calculator. Among them, only 76 farmers were willing to participate. The random sampling technique was used because of the respondents' distribution across the province; each farmer had equal chances of selection.

\section{Data collection method}

The data was obtained from a primary source through a self-structured questionnaire based on the objectives of the study. The questionnaire was sectioned into three parts; section (A) solicited their socio-economic characteristics, section (B) elicited information on the factors that influenced food security while section (C) detailed information about the constraints to food security in the study area.

\section{DATA ANALYSIS}

The data for this study was analyzed through descriptive and inferential statistics (Probit regression and Logistic regression) on STATA 13 and SPSS 23 (2015) software.

\section{Logistic Regression Model (LRM)}

The logistic regression model was employed to determine the factors that influenced food security level among farming households in the province. The binary logistic regression model is stated as:

$$
\mathrm{Yi}=\beta_{0}+\beta_{1} X_{1}+\beta_{2} X_{2}+\ldots+\beta_{n} X_{n}
$$

$\mathrm{Yi}$ is a binary variable which is 0 if respondents are food secure, and 1 otherwise. $\beta_{0}$ is the intercept (constant); $\beta_{1}, \beta_{2}$, to $\beta \mathrm{n}$ are the regression coefficients of predictor variables, $X_{1}, X_{2}$, and $X_{n}$, respectively (i.e. $X_{1}=$ Age of household's head, $X_{2}=$ Gender of household's head, $X_{3}$ $=$ Educational level, $X_{4}=$ Mortality level, $X_{5}=$ Household's feeding rate, $X_{6}=$ Extension visits on farm, $X_{7}=$ Total cost of production, $X_{8}=$ Farm income, $X_{9}=$ Receptivity to innovation, $X_{10}=$ Financial assistance, $X_{11}=$ Frequency of vaccination and $X_{12}=$ Health expenses). The logistic regression model is widely used to analyze data with dichotomous dependent variables (Kemalbay and Korkmazoğlu, 2014). It was considered a suitable model to use in this research because the dependent variable was dichotomous in nature. This method also allows for maximum-likelihood estimation even if there is a single response to the category. It reduces the amount of computation required and directly estimates the probability of an event, and is therefore considered commendable for this study. All variables that had several categories were regrouped to ease processing of the results.

\section{Probit Regression Model (PRM)}

The Probit regression model was fitted to analyze the constraints that affected food security among farming households in the North West province. This model was used as it is the standard method for estimating multi-category dependent variables, and because of the dichotomous nature of the dependent variable, a re-categorized food secure/food insecure dummy, as shown in the regression form (where 1 means food security and 0 means food insecurity). The model can then be specified as:

$$
\begin{gathered}
Z_{j}=\alpha+\beta_{j} \sum_{i=1}^{n} 1_{j}+u_{j} \\
\mathrm{Zi=} \alpha_{0}+\alpha_{1} X_{1}+\alpha_{2} X_{2}+\alpha_{3} X_{3}+\alpha_{4} X_{4}+\alpha_{5} X_{5}+ \\
+\alpha_{6} X_{6}+\alpha_{n} X_{n}+\ldots+\mathrm{ei}
\end{gathered}
$$

Where $Z_{j}$ is the binary (dummy) dependent variable indicating the households' nutritional status; equal to 0 if household is food secure and 1 otherwise

$\alpha$ and $\beta_{j}$ are the parameters of the estimates

$n$ - number of variables,

$\mu_{j}-$ Error term

$l_{j}$-independent variables $\left(X_{1}=\right.$ Age, $X_{2}=$ Educational level, $X_{3}=$ Household size, $X_{4}=$ Availability of food, $X_{5}=$ Veld fires, $X_{6}=$ Theft of animal, $X_{7}=$ Disease infestation, $X_{8}=$ Market availability, $X_{9}=$ Predator invasion, $X_{10}=$ Poor livestock condition, $X_{11}=$ Lack of infrastructure, $X_{12}=$ Health expenses, $X_{13}=$ Access to veterinary services).

\section{RESULTS AND DISCUSSION}

\section{Socio-economic characteristics of the respondents in the study area}

Table 1 shows that majority of the farming households (28.9\%) were in the 51-60 age bracket. This indicates that most of these farming households are old; this could contribute to their low productivity and hence food insecurity status. This result is consistent with the 
Ijatuyi, E. J., Omotayo, A. O., Nkonki-Mandleni, B. (2018). Empirical analysis of food security status of agricultural households in the platinum province of South Africa. J. Agribus. Rural Dev., 1(47), 29-38. http://dx.doi.org/10.17306/J.JARD.2018.00397

Table 1. Socio-economic characteristics of the respondents

\begin{tabular}{|c|c|c|c|}
\hline Variable & Frequency & Percentage & Mean \\
\hline \multicolumn{4}{|l|}{ Age } \\
\hline $20-30$ & 13 & 17.20 & \\
\hline $31-40$ & 18 & 23.70 & \\
\hline $41-50$ & 10 & 13.20 & \\
\hline $51-60$ & 22 & 28.90 & 55 years \\
\hline $61-70$ & 9 & 11.80 & \\
\hline $71-80$ & 3 & 3.90 & \\
\hline $81-90$ & 1 & 1.30 & \\
\hline \multicolumn{4}{|l|}{ Gender } \\
\hline Male & 57 & 75.00 & \\
\hline Female & 19 & 25.00 & \\
\hline \multicolumn{4}{|l|}{ Household Size } \\
\hline 1-4 members & 31 & 40.8 & \\
\hline 5-8 members & 37 & 48.6 & 5 members \\
\hline 9-12 members & 8 & 10.6 & \\
\hline \multicolumn{4}{|l|}{ Educational level } \\
\hline $\begin{array}{l}\text { High school } \\
\text { graduate }\end{array}$ & 25 & 32.9 & \\
\hline Diploma & 10 & 13.2 & \\
\hline Degree & 7 & 9.2 & \\
\hline Other/Standard & 33 & 43.4 & \\
\hline None & 1 & 1.3 & \\
\hline \multicolumn{4}{|l|}{$\begin{array}{l}\text { Total Annual Income } \\
\text { (Rand) }\end{array}$} \\
\hline $1-40,000$ & 26 & 34.2 & \\
\hline $40,001-80,000$ & 34 & 44.9 & 50,000 \\
\hline $80,001-120,000$ & 11 & 14.4 & \\
\hline $120,001-160,000$ & 2 & 2.6 & \\
\hline $160,001-200,000$ & 3 & 3.9 & \\
\hline Total & 76 & 100 & \\
\hline
\end{tabular}

Source: own research.

findings of D'Haese et al. (2011) who noted activity in the 51-60 age bracket as well. More so, the majority (75 percent) of the respondents were male while female respondents represented only 25 percent. This is in line with most literature on rural communities of Africa as agriculture is mostly seen as men's business due to its labor-demanding nature. Also, this complies with the findings of Omotesho et al. (2007), who had 97.7 percent of the respondents in his study to be men. Irohibe and Agwu (2014) also discovered that the majority of the respondents were male, with a share of 89.2 percent.

In addition, most (48.6\%) of the respondents' household had a size ranging from 5 to 8 members, with an average household size of 5 in the study. This indicates a considerably moderate households' size in the study area. The result is consistent with the findings of Abur (2014), Abu and Soom (2016) who found the household size in their study area to be between 7 and 9 members. As regards the respondents' educational level, 43.4 percent of them had standard education, 32.9 were high school graduates; those with diploma degree and degree holders had a share of 13.2 percent and 9.2 percent, respectively. However, 1.3 percent had no formal education. This implies that education is an important weapon in the battle against poverty and food insecurity. This finding is in line with Ogunkoya (2014) who supported the results by showing that in her study area, the majority of respondents had a standard form of education.

Finally, the study shows that the majority of respondents $(44.9 \%)$ received an annual income ranging from ZAR 40,000 to ZAR 80,000 while 34.2 percent earned between ZAR 1 and ZAR 40,000. Furthermore, 14.40 percent, 3.9 percent and 2.6 percent of the respondents reported an annual income of ZAR 80,001 to ZAR 120,000; ZAR 160,001 to ZAR 200,000; and ZAR 120,001 to ZAR 160,000 , respectively, with an average level of ZAR 50,000. This is in accordance with the statement from D'Haese et al. (2011) that families with financial resources escape extreme poverty and chronic hunger. Also, FAO (2003) highlighted that the households' income is an important co-determinant of food security. Furthermore, Abu and Soom (2016) stated that as the income of the household improves, ceteris paribus, so does the probability of the household being food secure.

\section{Food security level of respondents in the study area}

Table 2 revealed that 56.58 percent of the farming households were food insecure while 43.42 percent were found to be food secure based on the food security index constructed (that is $2 / 3$ mean per capita food expenditure) in the study. 
ljatuyi, E. J., Omotayo, A. O., Nkonki-Mandleni, B. (2018). Empirical analysis of food security status of agricultural households in the platinum province of South Africa. J. Agribus. Rural Dev., 1(47), 29-38. http://dx.doi.org/10.17306/J.JARD.2018.00397

Table 2. Food security status of the respondents

\begin{tabular}{lcc}
\hline \multicolumn{1}{c}{ Variable } & Frequency & Percentage \\
\hline Food secure & 33 & 43.42 \\
Food insecure & 43 & 56.58 \\
\hline Total & 76 & 100 \\
\hline
\end{tabular}

Source: own research.

Logistic regression model for factors that influenced food security level of the farming households in the study area

Logistic regression results for factors that influenced food security among the rural farming households in the North West province are shown in Table 3. Marginal effects of the variables were provided and the test for multicollinearity among the variables was carried out with Variance Inflation Factor (VIF), giving a mean VIF of
1.48 (see Table 4). A high level of tolerance computed for the variables indicates that there was no significant multicollinearity in the analysis. Variables with negative parameters implied a negative relationship with the dependent variable while those with positive coefficients implied a positive relationship with the dependent variable.

In this study, variables such as age of the household's head, household feeding rate, the total cost of production, income made from the sale of farm animals/ produce and health expenditure were significant to the respondent's food security at 5 percent, i.e. $p<0.05$. However, other variables, such as gender of the households' head, extension visits to farms, level of receptivity to new or improved farming techniques and frequency in vaccination, were significant to food security at $p<0.10$. The parameter representing the age of the farming households' head was positive (0.4178) and

Table 3. Logistic regression results of the factors influencing food security levels in the North West province

\begin{tabular}{|c|c|c|c|c|c|c|}
\hline Food security & Coefficient & Std. Error & $\mathrm{Z}$ & $\mathrm{P}>\mid \mathrm{z}$ & $\begin{array}{c}\text { Marginal } \\
\text { Effect }\end{array}$ & Tolerance \\
\hline Age & 0.417876 & 0.1964109 & 2.13 & 0.033 & $2.28 \mathrm{e}-07$ & 0.7579 \\
\hline Gender & 9.300633 & 5.026487 & 1.85 & 0.064 & $5.56 \mathrm{e}-06$ & 0.8890 \\
\hline Educational level & -0.9952774 & 0.8401385 & -1.18 & 0.236 & $-5.42 \mathrm{e}-07$ & 0.7418 \\
\hline Mortality level & -33.0405 & 4528.129 & -0.01 & 0.994 & -.999999 & 0.5494 \\
\hline Households feeding rate & -12.06119 & 5.965438 & -2.02 & 0.043 & $-6.57 \mathrm{e}-06$ & 0.8381 \\
\hline Extension visit on farm & -5.078587 & 2.949552 & -1.72 & 0.085 & $-2.77 \mathrm{e}-06$ & 0.8318 \\
\hline Total cost of production & 0.0038975 & 0.001799 & 2.17 & 0.030 & $2.12 \mathrm{e}-09$ & 0.7476 \\
\hline Farm income & 11.52203 & 5.351363 & 2.15 & 0.031 & $6.28 \mathrm{e}-06$ & 0.5589 \\
\hline Farmers receptivity to innovation & 7.75096 & 4.189148 & 1.85 & 0.064 & $4.22 \mathrm{e}-06$ & 0.8766 \\
\hline Financial assistance & -13.89101 & 4528.123 & -0.00 & 0.998 & $-7.03 \mathrm{e}-06$ & 0.6569 \\
\hline Vaccination frequency & -1.460569 & 0.8560479 & -1.71 & 0.088 & $-7.96 \mathrm{e}-07$ & 0.8119 \\
\hline Health expenditure & -4.347126 & 2.126998 & -2.04 & 0.041 & $-2.37 \mathrm{e}-06$ & 0.6588 \\
\hline Constant & 1.851305 & 4528.13 & 0.00 & 1.000 & & \\
\hline Observation number & 76 & & & & & \\
\hline $\operatorname{LR~chi}^{2}(12)$ & 76.67 & & & & & \\
\hline Prob $>$ chi $^{2}$ & 0.0000 & & & & & \\
\hline Pseudo R ${ }^{2}$ & 0.8228 & & & & & \\
\hline Log likelihood & -8.2575465 & & & & & \\
\hline
\end{tabular}

Source: own research. 
Ijatuyi, E. J., Omotayo, A. O., Nkonki-Mandleni, B. (2018). Empirical analysis of food security status of agricultural households in the platinum province of South Africa. J. Agribus. Rural Dev., 1(47), 29-38. http://dx.doi.org/10.17306/J.JARD.2018.00397

Table 4. Multicollinearity test of variables

\begin{tabular}{lccc}
\hline \multicolumn{1}{c}{ Variables } & VIF & Tolerance & Eigenvalue \\
\hline Food security & 2.61 & 0.3833 & 9.0241 \\
Age & 1.32 & 0.7579 & 1.1908 \\
Gender & 1.12 & 0.8890 & 0.8435 \\
Educational level & 1.35 & 0.7418 & 0.6883 \\
Mortality level & 1.82 & 0.5494 & 0.5902 \\
Households feeding rate & 1.22 & 0.8209 & 0.4793 \\
Extension visit on farm & 1.20 & 0.8318 & 0.4043 \\
Total cost of production & 1.34 & 0.7476 & 0.3294 \\
Farm income & 1.79 & 0.5589 & 0.1615 \\
Farmers receptivity to & 1.14 & 0.8766 & 0.0871 \\
innovation & & & \\
Financial assistance & 1.52 & 0.6569 & 0.0711 \\
Vaccination frequency & 1.23 & 0.8119 & 0.0650 \\
Health expenditure & 1.52 & 0.6588 & 0.0539 \\
Mean VIF & 1.48 & & \\
\hline
\end{tabular}

Source: own research.

significant at $p$ value less than 5 percent i.e. $p<0.05$ This implies a direct and positive relationship between the farming households' age and their food security status in the study area. This further indicates that the older the farmers in the study area, the higher is the probability of them being food secure. This result is consistent with the findings of Agwu and Oteh (2014) but contradicts the study of Omonona et al. (2007) where age of the household head did not positively affect food security.

In addition, the coefficient of the respondents' feeding rate was negatively significant at $p<0.05$ which means that a higher respondents feeding rate leads to food insecurity in the study area. This is not expected as higher food consumption ought to result in the food security status for the respondents. However, this could be characteristic to the study area as the food intake of the respondents may be based on the same type of meal which could be deficient of adequate nutrient required for strength and vitality. On the other hand, the cost of production statistically exhibited a positive (0.00389) and significant $(p<0.05)$ relationship to the respondents' food security status.

In the same vein, the parameter of household heads' income was positive (11.52203) and significant (at $p<0.05)$.
This implies that as the income from sales of farm produce increases, so does the probability of food security among the farming households, since they gain a higher purchasing power. This is consistent with the findings of Agwu and Oteh (2014); Waggins and Keats (2009) who found income to have a positive influence on the households' food security. Finally, the coefficient of the farming households' health expenses was negative $(-4.3471)$ and significant (at $p<0.05)$. This indicates that the lower the respondents' health expenditure, the more food secure the households are. This is expected as health expenditure has been affirmed by existing literature to strongly erode the financial base of rural farming households, always affecting their food security status.

\section{Constraints for food security among farming households in the North West Province}

Table 5 presents the results from the Probit model analysis for the constraints affecting the achievement of food security among farming households in the North West Province. In this case, the re-categorized dummy form of the food security score, as shown in the regression formula (where the food security scores was 0 if the respondent was food secure, and 1 if otherwise), was used as a dependent variable regressed against the explanatory variables. In order to avoid inconsistency and bias from the estimated parameters, the study subjected the variables to a multicollinearity test using the Collin command in STATA. The Variance Inflation Factor (VIF) was also used to test the multicollinearity among variables.

Eight out of the thirteen variables analyzed were the found to be constraints that significantly influence the achievement of food security in the study area. These included the age of households head, availability of food, veld fire, market availability, predator invasion, lack of infrastructures, health expenditure, and veterinary practices. The age parameter was statistically significant at $p<0.05$ and had a positive coefficient of 0.1404625 . This means that an increase in age increases food security level among respondents in the study area. This result is contrary to the findings of Abu and Soom (2016) who stated that age had a negative relationship with household food security.

Expectedly, the coefficient of the availability of food among respondents in the study area was found to be positively significant at $p<0.05$. This implies that as 
Ijatuyi, E. J., Omotayo, A. O., Nkonki-Mandleni, B. (2018). Empirical analysis of food security status of agricultural households in the platinum province of South Africa. J. Agribus. Rural Dev., 1(47), 29-38. http://dx.doi.org/10.17306/J.JARD.2018.00397

Table 5. Constraints of food security among farming households in the North West province

\begin{tabular}{lcccc}
\hline \multicolumn{1}{c}{ Food security } & Coefficient & Std. Err & $\mathrm{Z}$ & $\mathrm{P}>\mid \mathrm{Z}$ \\
\hline Age & 0.1404625 & .0548776 & 2.56 & 0.010 \\
Educational level & -0.4320244 & .4208088 & -1.03 & 0.305 \\
Household size & -0.0494765 & .1384519 & -0.36 & 0.721 \\
Availability of food & 1.240906 & .6295198 & 1.97 & 0.049 \\
Veld fires & -1.48316 & .7451711 & -1.99 & 0.047 \\
Theft of animals & 0.6898716 & .43428 & 1.59 & 0.112 \\
Disease infestation & -0.8561975 & .5738236 & -1.49 & 0.136 \\
Market availability & -0.749338 & .303668 & -2.47 & 0.014 \\
Predator invasion & 2.387832 & 1.156968 & 2.06 & 0.039 \\
Poor livestock condition & -0.0976465 & .3507808 & -0.28 & 0.781 \\
Lack of infrastructure & -1.691381 & .6458054 & -2.62 & 0.009 \\
Health expenditure & -2.391812 & 1.167779 & -2.05 & 0.041 \\
Veterinary practices & 3.10221 & 1.032261 & 3.01 & 0.003 \\
\hline Constant & -1.819591 & 2.144622 & -0.85 & 0.396 \\
Number of observations & 76 & & & \\
LR Chi ${ }^{2}$ (13) & 65.57 & & & \\
Prob $>$ chi ${ }^{2}$ & 0.0000 & 0.7037 & & \\
Pseudo $r^{2}$ & -13.807445 & & & \\
Log likelihood & & & & \\
\hline
\end{tabular}

Source: own research.

the adequate access to food and food supplements by respondents improved, so did their food security level. This is in line with a priori knowledge as adequate access to food is a dimension of food security. In addition, the coefficient of veld fire was statistically negative $(-1.48316)$ and significant (at 5 percent) for the level of food security among respondents in the study area $(p<$ $0.05)$. This implies that an increase in the risk of fire affecting the respondents' farms and animals lessen their probability of being food secure in the study area. This is in line with the a priori expectation, because environmental hazards such as veld fire are a shock that automatically affects the rural farming households' revenue and food security status.

Market availability was found to be negatively significant $(-0.74934)$ to the food security status among respondents at $p<0.05$. This implies that the poorer the market availability level of the farming households, the more food secure they were which is not in line with the a priori expectation from the study. However, it might be because the lack of proper marketing channels for the farming households makes them change their mind and decide to consume such produce in order to prevent wastage. This is a "situation of induced food security status" which is mostly transient in nature. It is common in the rural settings where there is no proper market for farm produce.

Predator invasion suffered by the respondents in the study area was found to be significant (2.3878) at $p<0.05$. This indicates that a rise in the number of wild animal attacks on the farmers' livestock or crops increases the probability of the farming households being food secure. This does not corroborate the a prio$r i$ expectation as predator attacks on farm produce are supposed to reduce the farming outcome and revenue, and should therefore invariably lead to food insecurity 
Ijatuyi, E. J., Omotayo, A. O., Nkonki-Mandleni, B. (2018). Empirical analysis of food security status of agricultural households in the platinum province of South Africa. J. Agribus. Rural Dev., 1(47), 29-38. http://dx.doi.org/10.17306/J.JARD.2018.00397

Table 6. Multicollinearity test of the variables

\begin{tabular}{lccc}
\hline \multicolumn{1}{c}{ Variables } & VIF & Tolerance & Eigenvalue \\
\hline Food security & 2.24 & 0.4467 & 11.9505 \\
Age & 1.73 & 0.5784 & 0.8073 \\
Educational level & 1.34 & 0.7464 & 0.4717 \\
Household size & 1.22 & 0.8225 & 0.3404 \\
Availability of food & 1.71 & 0.5848 & 0.3108 \\
Veld fire & 2.41 & 0.4155 & 0.2785 \\
Theft of animal & 1.78 & 0.5609 & 0.1976 \\
Disease infestation & 1.70 & 0.5878 & 0.1670 \\
Market availability & 1.77 & 0.5648 & 0.1399 \\
Predator invasion & 3.38 & 0.2960 & 0.0873 \\
Poor livestock condition & 2.21 & 0.4522 & 0.0814 \\
Lack of infrastructure & 2.47 & 0.4049 & 0.0656 \\
Health expenditure & 3.03 & 0.4916 & 0.0462 \\
Veterinary practices & 2.04 & 0.4908 & 0.0336 \\
Mean VIF & 2.00 & & \\
\hline
\end{tabular}

Source: own research.

of the farming households. Conclusively, the health expenses parameter was found to be negatively significant $(-2.391812)$ at 5 percent, i.e. $p<0.05$ for the food security of rural farming households. This by implication indicates that the lower the amount expended by respondents on their health, the better their food security status. This can be due to the fact that smaller health expenses enable more savings; this results in a better budget situation and higher expenses on food which, in turn, lead to food security of the farming households.

\section{CONCLUSION AND RECOMMENDATION}

This paper analyzed the factors and constraints that influenced food security among the farming households in the North West province of South Africa. This study evidently brought to limelight some salient policy-relevant issues that should be urgently addressed in order to mitigate the food insecurity issues among the rural farming households in this province. In conclusion, the rural farming households in the North West province witness different dimensions of food (in)security which obviously affect different aspects of their social and economic activities even on a daily basis. Another key identified aspect of food security in this study is food availability and accessibility which - apart from being the two major pillars of food security - were found to statistically influence food security in the study area.

The South African government should ensure that the teaming unemployed youth are encouraged to practice agriculture so as to replace the ageing farmers in the rural farming households in the province. Adequate arrangements for credit facilities for willing farmers should be provided, together with a regular distribution of farming incentives to farmers at regulated prices, especially in the province. There is also a need to provide adequate education to facilitate the farmers' receptivity to new innovations. Since the rural farmers suffer from constraints/shocks such as veld fire, predator invasion, lack of infrastructure, the government should provide a favorable farming environment, such as infrastructural facilities, to the farming households. The onus, therefore, is on the government to provide a holistic approach to the discrepancy in the national and grass-roots food security status of South Africa, so as to effect a timely intervention in order to rescue the most vulnerable farmers who are rural dwellers.

\section{REFERENCES}

Abu, G. A., Soom, A. (2016). Analysis of factors affecting food security in rural and urban farming households of Benue State, Nigeria. Int. J. Food Agric. Econ., 4(1), $55-68$.

Abur, C. C. (2014). Assessment of Food Security Status among Rural Farming Households in Guma Local Government Area of Benue State, Nigeria. Int. J. Hum. Soc. Sci., 1(2), 34-42.

Agwu, N. M., Oteh, O. U. (2014). Analysis of income inequalities and food security among farmers in Abia State, South Eastern Nigeria. Scientific Papers Series Management, Econ. Eng. Agric. Rural Dev., 14(3), 7-13.

Alem, Y., Köhlin, G., Stage, J. (2014). The persistence of subjective Poverty in urban Ethiopia. World Develop., 56, $51-61$.

Altman, M., Hart, T. Jacobs, P. (2009). Food security in South Africa. Pretoria, South Africa: Human Science Research Council.

Blignaut, J. N., De Wit, M. P., Knot, J., Midgley, S., Crookes, D. J., Drimie, S. Nkambule, N. P. (2014). Sustainable agriculture: A viable option for enhanced food and nutritional security and a sustainable productive resource base 
Ijatuyi, E. J., Omotayo, A. O., Nkonki-Mandleni, B. (2018). Empirical analysis of food security status of agricultural households in the platinum province of South Africa. J. Agribus. Rural Dev., 1(47), 29-38. http://dx.doi.org/10.17306/J.JARD.2018.00397

in South Africa: An investigation. Baseline Review. Prepared for the Development Bank Southern Africa. Pretoria: ASSET Research.

DAFF (2016). Abstract of Agricultural statistics. Pretoria, South Africa.

De Cock, N., D’Haese, M., Vink, N., Van Rooyen, C. J., Staelens, L., Schönfeldt, H. C., D’Haese, L. (2013). Food security in rural areas of Limpopo province, South Africa. Spring. J., 5, 269-282.

D’Haese, L., Van Rooyen, J., Vink, N., Kirsten, J., Staelens, L., Van-damme, E., Shönfeld, H., Remaut-Dewinter, A. M., D'Haese, M. (2011). Food security: Limpopo Province. Retrieved Dec 12th 2016 from: http://www.up.ac.za/ media/shared/Legacy/sitefiles/file/48/4153/finalreportlimpopoprojet2011.pdf

FAO (2003). Trade reforms and food securitu. Rome: FAO.

Ijatuyi, E. J. (2016). Assessment of extension and advisory services on Nguni cattle development project beneficiaries in North West province. Unpublished MSc dissertation, North-West University, South Africa.

Kemalbay, G., Korkmazoğlu, Ö. B. (2014). Categorical Principal Component Logistic Regression: A Case Study for Housing Loan Approval. Proc. Soc. Behav. Sci., 109, 730-736.

Krejcie, R. V., Morgan, D. W. (1970). Determining sample size for research activities. Edu. Psych. Meas., 30(1), 607-610.

Irohibe, I. J., Agwu, A. E. (2014). Assessment of Food Security Situation among Farming Households in Rural Areas of Kano State, Nigeria. J. Cen. Euro Agri., 15(1), 94-107.

Labadarios, D., Davids, Y. D., Mchiza, Z., Weir-Smith, G. (2009). The assessment of food insecurity in South Africa. Pretoria: Centre for Poverty, Employment, and Growth, Human Sciences Research Council.

NDA (2013). South Africa yearbook 2013/14 on Agriculture. Pretoria, South Africa.
Ogunkoya, F. T. (2014). Socioeconomic factors that affect livestock numbers: A case study of smallholder cattle and sheep farmers in the Free State province of South-Africa. Submitted for the degree of Master of Science in Agriculture. South Africa: University of South Africa.

Oluwatayo, I. B., Rachoene, M. A. (2017). Effect of Agricultural Commercialization on Food Security among smallholder farmers in Polokwane Municipality, Capricorn District of Limpopo Province, South Africa. J. Agribus Rur Develop., 1(43), 143-156.

Omonona, B. T., Oni, O. A., Akpan, E. (2007). The Determinants of Demand for Nigeria's Agricultural Export Commodities. Pakis. J. Soc. Sci., 4(2), 247-251.

Omotesho, O. A., Adewumi, M. O., Fadimula, K. S. (2007). Food Security and Poverty of the Rural Households in Kwara State, Nigeria. AAAE Conference Proceedings, 571-575.

Shisana, O., Labadarios, D., Rehle, T., Simbayil, L., Zuma, K., Dhansay, A., Reddy, P., Parker, W., Hoosain, E., Naidoo, P., Hongoro, C., Mchiza, Z., Steyn, N. P., Dwane, N., Makoae, M., Maluleke, T., Ramlagan, S., Zungu, N., Evans, M. G., Jacobs, L., Faber, M., \& SANHANES-1 Team. (2013). South African National Health and Nutrition Examination Survery. Capetown, South Africa: HSRC press.

Shuttleworth, M. (2008). Descriptive research design. Retrieved June 20th 2017 from https:/explorable.com/ descriptive-research-design

Waggins, S., Keats, S. (2009). Current State of Food Security in African and Africa-Eu partnership on the Millennium Development Goals. A paper for the 2nd Joints Experts Growing Meeting, Africa-EU MDGS Partnership, subgroup on priority Action 2: Accelerate the food security targets of the MDGs. Pretoria, South Africa. March, 24. 